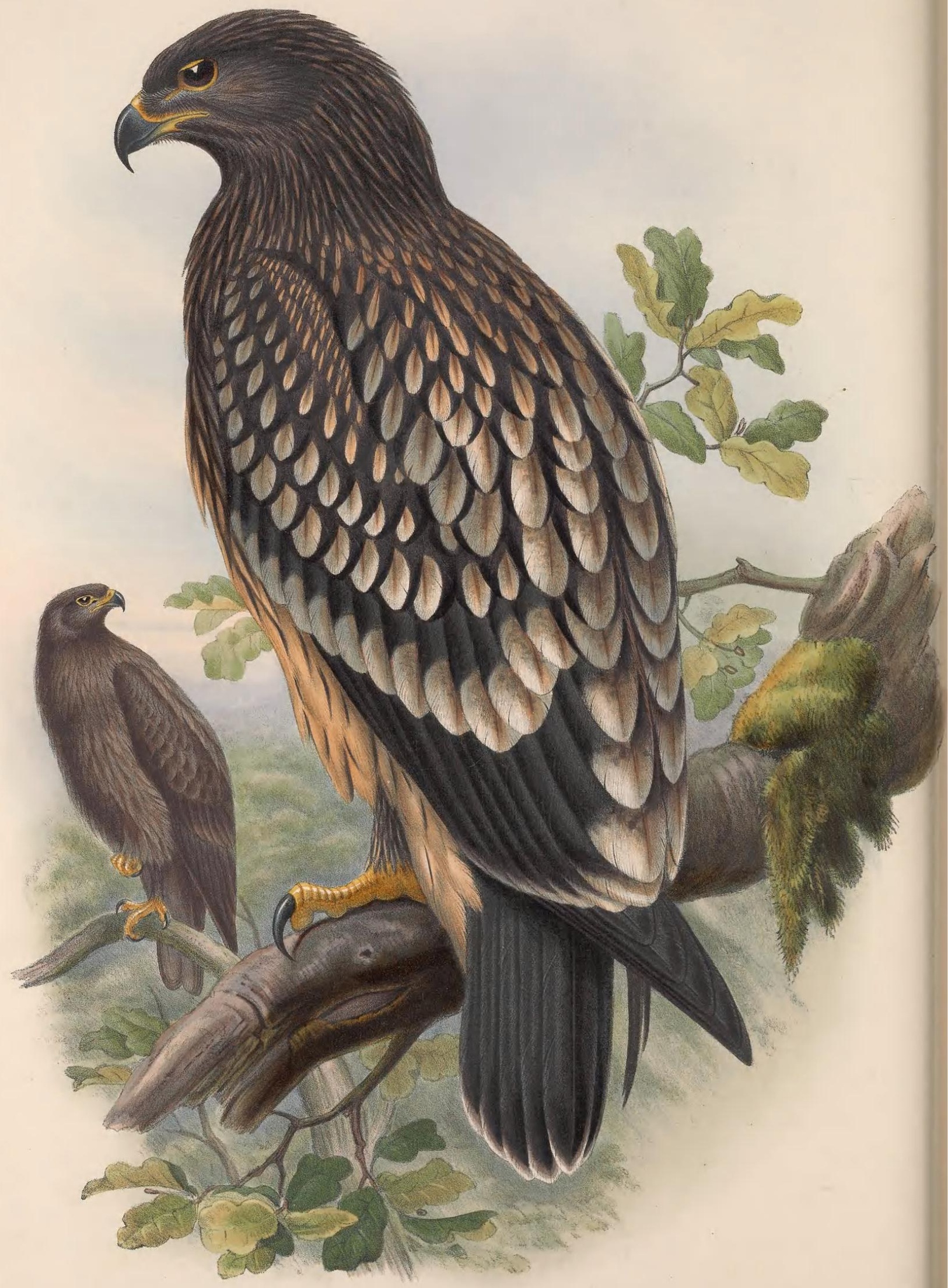




\section{AQUILA NAVIA.}

\section{Spotted Eagle.}

Falco nøius et maculatus, Gmel. edit, Linn. Syst. Nat., tom. i. p. 258.

Aquila nøvia, Meyer, Taschenb. Deutschl. Vög., tom. i. p. 19.

pomarina, Brehm, Vög. Deutschl., tom. i. p. 27.

planga, Vieill. Ency. Méth. Orn., part iii. p. 1190.

bifasciata, Hornsch.

melanaëtos, Savig. Descr. de l'Egypte, Hist. Nat., tom. i. p. 84 ,

vittata, Hodgs. in Gray's Zool. Misc., 1844, p. 81 ?

anatraja, Savi, Orn. Tosc., tom. ii. p. 22.

Spizaëtus fuscus, Vieill. Nouv. Dict. d'Hist. Nat., tom. xxxii. p. 60.

Although the Spotted Eagle is one of the smallest members of its genus, it is in every respect a true Aquila; and had it been a native of the British Islands instead of an accidental visitor, it would have been an important species in the Raptorial division of our avifauna. In Mr. Rodd's useful 'List of British Birds as a guide to the Ornithology of Cornwall,' two instances are given of its occurrence in that county in the following words:-

"The capture of the first English example of this rare Eagle took place on the 4th of December, 1860, in the eastern part of Cornwall, at a large covert called Hawk's Wood, the property of Francis Rodd, Esq., of Trebartha Hall, adjoining the large moors between Hawk's Tor and Kilmar, and not very far from the well-known Cheese-wring. Hawk's Tor and Kilmar Tor rank amongst the highest hills in Cornwall, reaching in altitude from 1000 to 1200 feet; the characters of these hills and the moors about them in every direction are exactly similar to those on Dartmoor; in fact, the range is a continuation of the great granite tract extending, with some few interruptions, to the Land's-end. The bird was first observed in a tree, from which, on the approach of the shooting party, instead of soaring, it shuffled down, and scrambled under some rocks; its condition was beyond the average of birds of prey, large masses of fat encircling the gizzard, which, on dissection, was entirely empty; one of the wing-bones was broken, but whether with shot or otherwise I could not determine; the body, wings, and every part of the bird exhibited the most perfect form; but probably the injury above mentioned prevented it from taking flight. It was a male in the first year's plumage, and weighed $4 \mathrm{Jbs} .1 \mathrm{oz}$.

"A second example, almost in a similar state of plumage, was killed near Carnanton, in November, 1861 ; it is now in the Truro Museum," whence it was kindly sent up to London for my use; and my best thanks are here offered to Dr. Barham and the Council of the Royal Institution of Cornwall for the service they thus rendered to the present work. It will be seen by the hinder figure how much the young and adult differ in plumage. No other species of Aquila, in fact, offers so great a contrast, the livery in the latter state being nearly uniform in colour, while the other is so much marked and ornamented. It is somewhat strange that this continental species should have visited one of our southern counties, while, according to Mr. Rodd, the Golden Eagle, a bird which commonly breeds in Scotland, should never have been seen there; it forms another instance in exemplification of the western movement of Continental species.

Although I have given precedence to the English-killed specimens of the Spotted Eagle, I must not fail to state that a place in our avifauna was first assigned to it by Mr. Yarrell in the supplement to lis 'History of British Birds,' where he says, "For the particulars of the occurrence of this interesting addition to the ornithology of the British Islands, I an indebted to Mr. Robert Davis, jun., of Clonmel. "This specimen," observes Mr. Davis, "was shot on the estate of the Earl of Shannon, and was at the time in a fallow field devouring a rabbit. Another bird similarly marked, but reported to be of a lighter shade of brown, was shot at the same place within a few days, but unfortunately was not preserved; both had been noticed during the two previous months, sweeping over the low grounds in the neighbourhood, which is near Youghal, and between Castle Martyr aud Clay Castle."

The proper home of the Aquila ncevia is the southern and eastern countries of Europe, North Africa, Asia Minor, Palestine, and probably Western India; I say probably, because the bird inhabiting the Indian Peninsula has by some writers been considered distinct; but Mr. Blyth, no mean authority, believes in their identity, and says the bird is also abundant in the Himalayas, and in the wooded and watery portions of Central and Southern India. 


\section{$2 \mathrm{BHL}$ Biodiversity Heritage Library}

Gould, John. 1873. "Spotted Eagle, Aquilla nævia [PI. 3]." The birds of Great Britain 1, -. https://doi.org/10.5962/p.323786.

View This Item Online: https://www.biodiversitylibrary.org/item/221495

DOI: https://doi.org/10.5962/p.323786

Permalink: https://www.biodiversitylibrary.org/partpdf/323786

\section{Holding Institution}

Smithsonian Libraries

\section{Sponsored by}

Biodiversity Heritage Library

\section{Copyright \& Reuse}

Copyright Status: Public domain. The BHL considers that this work is no longer under copyright protection.

This document was created from content at the Biodiversity Heritage Library, the world's largest open access digital library for biodiversity literature and archives. Visit BHL at https://www.biodiversitylibrary.org. 